\title{
LINHAS RETAS OU LABIRINTOS? A tradução da sociologia da modernização nos textos de Florestan Fernandes e de Gino Germani (1960-1970)*
}

\section{Antonio Brasil Jr.}

De acordo com as narrativas canônicas da história da sociologia, o período que se inicia em 1950 e que se estende até meados dos anos de 1970 poderia ser visto como a história da emergência, consolidação, crítica e dissolução do "consenso ortodoxo" organizado em torno do "estrutural-funcionalismo”, em suas inúmeras variações (Giddens, 2003). Processo que seria acompanhado, em termos geográficos, pelo deslocamento do centro dinâmico da disciplina da Europa para os Estados Unidos (Hughes, 1975), onde figuras como Talcott

* Este artigo é uma versão condensada da última parte de minha tese de doutorado (Brasil Jr., 2011), cuja versão em livro sairá em breve. Gostaria de aproveitar esta oportunidade para agradecer a André Botelho orientador da tese - pelo diálogo sempre constante, e aos demais pesquisadores da área de pensamento social pelo acolhimento no gt da anpocs, especialmente Elide R. Bastos, Nísia T. Lima e Angela Alonso.
Parsons, Robert K. Merton, Paul Lazarsfeld, entre outros, constituiriam suas novas lideranças intelectuais (Steinmetz, 2007a).

No entanto, contemporaneamente esta imagem vem sendo amplamente reelaborada, seja pela enorme simplificação que ela realiza da própria sociologia norte-americana daquele período (Calhoun e VanAntwerpen, 2007), seja pelo espaço exíguo que ela confere a produções situadas no amplo espectro das sociologias periféricas (Connell, 2006). Cabe lembrar que foi justamente neste período que, graças a iniciativas locais e internacionais - sobretudo através da atuação da unesco -, vários países conseguiram consolidar institucionalmente seus centros de produção sociológica (Maio, 1997). No caso da América Latina, por exemplo, cidades como São Paulo, Rio de Janeiro, Buenos Aires, Santiago de Chile e Cidade do México conheceram uma importante e diversificada atividade neste campo, como têm demonstrado os recentes 
trabalhos dedicados à sociologia latino-americana (Blanco, 2007; Trindade, 2007). Além disso, encontra-se em curso uma série de tentativas de "descentramento" da teoria sociológica, cujo objetivo é dar visibilidade a uma cartografia ampliada da disciplina, para além do eixo Europa-Estados Unidos (Maia, 2012).

Para que esta ampliação do quadro da sociologia seja feita de forma consistente, devemos estar atentos não só à diversidade de sociologias existentes, mas fundamentalmente às assimetrias que determinam a circulação de certos produtos - e não outros - no interior do conjunto por ela formado. Há posições centrais e periféricas que encaminham o fluxo de teorias, métodos e conceitos numa via quase de mão-única, cujos efeitos seria ocioso desconhecer (Beigel, 2010). Assim, a fim de se destacar uma possível relevância teórica da produção sociológica feita em paragens periféricas, torna-se incontornável apanhar os modos de "tradução" da matriz teórica dominante ao novo contexto social, bem como os deslocamentos que a própria tradução necessariamente implica. Afinal, dadas as linhas de força que conformam a disciplina, constitui tarefa inescapável ao sociólogo situado na periferia realizar um ajuste de contas crítico com a principal teorização de seu tempo. ${ }^{1}$

Neste artigo, trataremos, em linhas breves e esquemáticas, do processo de tradução realizado por Florestan Fernandes e Gino Germani da sociologia norte-americana, especialmente da chamada sociologia da modernização (Gilman, 2003). Nossa hipótese mais geral é que estes dois sociológicos, à testa dos dois principais centros de produção sociológica no Brasil e na Argentina, respectivamente, ${ }^{2}$ fizeram uma tradução bem-sucedida desta matriz teórica, que conheceu ampla difusão na virada dos anos de 1950-1960. Grosso modo, a sociologia da modernização tinha como pressuposto básico que o processo de expansão da sociedade moderna geraria sempre os mesmos efeitos sociais, ainda que a ritmos distintos, independentemente das trajetórias e das contingências históricas dos casos analisados. $\mathrm{Ou}$, como certa vez assinalou Reinhard Bendix (1967), como se a sociedade moderna fosse definida por um conjunto de variáveis sistêmicas interligadas e prontamente generalizáveis.
Percorrendo os principais textos de Fernandes e de Germani das décadas de 1960 e 1970, buscaremos demonstrar como, ao longo de um percurso de acumulação intelectual - fruto do contato intenso e paciente de ambos com as especificidades das sociedades brasileira e argentina -, os dois autores foram colocando em tensão as principais premissas da sociologia da modernização, sobretudo o pouco espaço que ela conferia à dimensão histórica da explicação sociológica. Noutras palavras, tanto Fernandes quanto Germani, ao traduzirem a sociologia da modernização, foram gerando, cada um a seu modo, produtos diferentes e dotados de certa criatividade teórica, cujo poder de interpelação nos interessa analisar. Com o intuito de assinalar este aspecto criativo das formulações de Fernandes e Germani, tomamos como instância de controle os textos de Talcott Parsons, tendo em vista a sua centralidade na sociologia norte-americana - e, por extensão, no conjunto da disciplina - do período. ${ }^{3}$ Embora Parsons não tenha sido propriamente um praticante da sociologia da modernização, sua atuação foi fundamental, tanto institucional quanto intelectualmente, para a sistematização desta vertente teórica (Brasil Jr., 2011, pp. 69-77). Daí que a comparação que ensaiamos aqui não se esgota numa díade: o contraste entre os textos de Fernandes e de Germani girará em torno da matriz teórica que ambos tiveram que traduzir - metonimizada, neste artigo, na produção parsoniana. A partir deste procedimento, poderemos enxergar como foram se conformando diferentes deslocamentos teóricos em relação à sociologia da modernização, já que os resultados a que chegaram os dois autores não são de modo algum intercambiáveis.

Como a tradução, neste registro, é um processo, e não um evento isolado, dividimos este texto em duas partes. A primeira, voltada para a comparação das produções de Fernandes e Germani na primeira metade da década de 1960 - sempre em confronto com Parsons -, procura mostrar que, antes mesmo de suas principais sínteses teóricas, ambos já tinham extravazado o sentido demasiado ordeiro da teorização estrutural-funcionalista vigente àquela altura. Por meio das noções "dilema social brasileiro" e "paradoxo argentino", discutiremos em que sentido as complicações históricas do Bra- 
sil e da Argentina foram pressionando a teorização para direções inesperadas vis-à-vis as premissas da sociologia da modernização. Já na segunda parte, analisaremos com mais detalhe as inovações teóricas divisadas em obras como $A$ revolução burguesa no Brasil [1975], de Fernandes, e La sociología de la modernización [1969], de Germani, livros nos quais os dois autores buscaram tirar o máximo de consequências teóricas das análises de suas respectivas sociedades. Ao final do artigo, algumas mediaçôes entre teoria sociológica e processo social serão sugeridas, como perspectiva analítica de observação do movimento da disciplina como um todo.

\section{Linhas retas ou labirintos?}

A despeito da imagem até hoje assentada de que Talcott Parsons apresenta uma visão muito otimista no que toca ao caráter irremediavelmente democrático da sociedade moderna, os avanços mais recentes em sua fortuna crítica vêm matizando esta percepção, especialmente ao tratarem de sua produção entre as décadas de 1940 e 1950 (Alexander, 1984, 1987; Gerhardt, 2002; Wearne, 2009). Embora não seja o caso de esmiuçarmos esta questão aqui, basta lembrarmo-nos do conjunto de textos de Parsons que trata dos processos de mudança social naquele contexto, como os dedicados à estrutura social da Alemanha de Weimar, à experiência nazista e à sociedade japonesa, reunidos em Essays in sociological theory [1949], ou mesmo o último capítulo do seminal The social system [1951]. Neste último livro, retrabalhando em sentido próprio a noção weberiana de racionalização e o conceito de cultural lag, formulado por William F. Ogburn, Parsons chama a atenção para os possíveis efeitos disruptivos da racionalização institucionalizada que seria típica da sociedade moderna, expressa particularmente na incorporação da ciência e da tecnologia na dinâmica das relaçôes sociais. Estabelecendo uma diferenciação máxima entre os papéis sociais desempenhados no complexo instrumental da sociedade - isto é, nas esferas relacionadas com o universo da produção material, crescentemente pautadas por critérios universalistas de desempenho e em inovação contínua - e nas demais solidarie- dades relacionais, como as relações comunitárias e de parentesco, a racionalização institucionalizada criaria desajustes permanentes entre o sistema de expectativas internalizado previamente pelos atores sociais e a situação social vigente, sempre móvel e cambiante (Parsons, 1964a, pp. 505-520). De acordo com Parsons, este desajuste, fonte de tensóes e instabilidades psíquicas e sociais agudas, poderia levar, como o autor tratou explicitamente em relação aos casos alemão e japonês, a experiências sociais trágicas e antidemocráticas, haja vista o descompasso que havia se formado entre o acelerado processo de industrialização e o acentuado formalismo das formas de estratificação social - impregnadas de distinçōes estamentais - naqueles dois países (Parsons, 1964b, pp. 123-141, 274-297).

Embora Parsons, neste período de sua produção, tenha sido claro ao afirmar que "todas as sociedades ocidentais têm estado sujeitas, em sua história recente, aos vários efeitos desorganizadores da rápida mudança tecnológica" (Idem, p. 117), para ele, a sociedade norte-americana, graças à fluidez de sua estratificação social, estaria em melhores condições de dissolver estas tensões que as sociedades europeias, por exemplo. Se nas últimas o enrijecimento das divisões de classe nem sempre se coadunava bem com a aceleração do processo de racionalização institucionalizada, os Estados Unidos, com sua estrutura social pluralista e pouco clivada em termos classistas, estaria em condições ótimas de levá-lo adiante de maneira relativamente equilibrada (Parsons, 1964a, pp. 514-515). Entretanto, mesmo essa relativa excepcionalidade da sociedade norte-americana não estaria isenta de problemas, posto que o surgimento do macarthismo no imediato pós-guerra teria colocado problemas em certa medida análogos aos enfrentados pelos países que experimentaram o fascismo (Parsons, 1969, pp. 157-184).

Em linhas gerais, é apenas na passagem dos anos de 1950 para a década seguinte que Parsons realmente articula uma visão positivada da sociedade moderna, cujos dinamismos seriam, nesta nova notação, particularmente democratizantes. Começando a esboçar o seu esquema agil de diferenciação sistêmica ao longo das quatro funções - economia (adaptação, a), sistema político [polity] (goal-at- 
tainment, g), comunidade societária (integração, i) e manutenção de padrão ou valores (latent pattern maintenance, l) - na publicação a quatro mãos com Niels Smelser, Economy and society [1956], podemos localizar especialmente em sua resenha a The power elite [1956], de Charles Wright Mills, a inflexão do autor no sentido de conectar diferenciação sistêmica e integração social democrática. Se até The social system, como vimos, a diferenciação estaria no próprio cerne das tensões (potencialmente) disruptivas inerentes à sociedade moderna, agora ela pressionaria por uma maior inclusão de indivíduos e grupos sociais na comunidade societária. Vejamos este ponto com mais vagar.

Na resenha ao livro de Mills, Parsons (1969, p. 199) desenvolve sua concepção de que a diferenciação de um sistema político não implicaria necessariamente a conformação de uma elite de poder voltada unicamente para a realização de seus interesses como se o poder fosse unicamente um jogo de soma zero. Contra Mills - e, em certo sentido, também contra Weber -, a diferenciação e a burocratização da esfera política não acarretariam somente uma maior concentração dos processos decisórios nas mãos de seus funcionários especializados, mas também uma circulação mais eficiente do poder por toda a sociedade, isto é, trariam ganhos coletivos. Como, para o autor, diferenciação sistêmica implica (e é condição para) maior complexidade social, a especialização da função política num subsistema relativamente autonomizado dos demais seria crucial para a continuidade da própria sociedade moderna. Além disso, os processos de diferenciação também seriam cruciais para pluralizar a estrutura social, no sentido de dissolver a rigidez dos vínculos particularistas de pertencimento, especialmente os ligados à religião, à família, à etnicidade e à origem de classe (Parsons, 1977, pp. 321-380). Funcionando, grosso modo, de modo especializado, tanto a economia quanto o sistema político orientariam os seus papéis sociais cada vez mais em torno dos valores (definidos através das variáveis-padrão) desempenho e universalismo, em contraposição à vigência da adscrição e do particularismo existentes sobretudo na (agora também especializada ) família conjugal (Parsons, 1970, pp. 129-154). E, para completar sua linha de raciocínio, Parsons assinala que, se a diferenciação sistêmica fortalece as orientações de valor universalistas, por um lado, e aumenta a complexidade social via pluralização da estrutura social, por outro, dois processos necessários decorrem daí: (a) generalização das orientações de valor [value generalization], que precisam legitimar normas sociais concretas cada vez mais diferenciadas em termos estruturais; (b) pressão pela inclusão de um número cada vez maior de indivíduos e coletividades (Idem, pp. 155-182).

O esquema esboçado certamente não faz justiça ao argumento parsoniano, muito mais complicado do que os pontos que sumarizamos aqui. No entanto, o que é essencial reter é a preocupação do autor em conectar os dinamismos que seriam típicos da sociedade moderna - os processos crescentes de diferenciação - com o fortalecimento de instâncias democráticas de integração social. Em termos sócio-históricos concretos, é interessante notar como este esquema conceitual é acionado na análise de Parsons da inclusão do negro na sociedade norte-americana. No artigo "Full citizenship for the Negro American? A sociological problem" [1965], posteriormente republicado em Sociological theory and modern society [1967], a despeito do tom dubitativo do título, o que vemos é uma narrativa histórica que associa fortemente diferenciação e inclusão. Situando, em primeiro lugar, a experiência bem-sucedida de integração à sociedade norte-americana dos judeus e dos católicos, ele mostra, no caso dos primeiros, por exemplo, que o desenvolvimento de empresas de grande escala, organizadas de modo mais burocrático e impessoal do que as antigas empresas familiares - um processo de diferenciação -, teria sido decisivo para a circulação dos judeus ao longo de toda a estrutura social, dissolvendo o difuso sentimento antissemita encontrado entre os grupos wasp (amparado na associação recorrente entre origem judaica e propriedade comercial). Ainda neste artigo de 1965, Parsons diz que o processo de extensão de plena cidadania ao negro norte-americano possivelmente seguiria, ainda que com especificidades (e provavelmente maior dificuldade), o mesmo padrão dos outros grupos sociais previamente excluídos. Analisando a atuação do movimento negro, para ele uma espécie de movimento socialista ao estilo norte-americano - 
já que suas demandas não se restringiriam apenas "à inclusão do negro como tal", mas se voltariam "para a eliminação de qualquer categoria definida como inferior" (Parsons, 1967, p. 454) -, a efervescência a ele associada seria indicativa de que estaria em curso nos Estados Unidos um processo de diferenciação máxima de uma comunidade societária (ou subsistema integrativo), quer dizer, de uma instância de solidariedade completamente autonomizada de restrições particularistas:

Hoje, mais do que nunca, estamos assistindo à aceleração do processo de emancipação dos indivíduos de todas as categorias destas solidariedades particularistas e difusas. Isso deve ser visto como uma diferenciação adicional no conjunto de papéis nos quais o indivíduo está envolvido. [...] Este raciocínio se aplica tanto a grupos aristocráticos quanto a grupos negativamente privilegiados, como os negros. Estamos testemunhando um passo decisivo na extensão e na consolidação da comunidade societária (Idem, p. 453).

Na medida em que, para Parsons, diferenciação não acarreta apenas especialização funcional mas também maior interpenetração entre os sistemas, as sucessivas diferenciações da economia e do sistema político teriam feito com que, à luz do padrão valorativo básico da sociedade norte-americana - nos termos do autor, um ativismo instrumental de corte universalista e igualitário (Parsons, 1970, pp. 159-165) -, “a única solução tolerável às enormes tensôes [existentes nos Estados Unidos] se [encontrasse] na constituição de uma única comunidade societária com participação total para todos" (Parsons, 1967, p. 455). Noutras palavras, não obstante os agudos conflitos levantados pelo associativismo negro na década de 1960, Parsons enxergava-os menos como sinais de crise da sociedade norte-americana e mais como uma dramatização histórica das pressôes por inclusão acarretadas por processos acelerados de diferenciação sistêmica.

A despeito do material histórico usado por Parsons, sobretudo a partir de meados dos anos de 1950, referir-se basicamente à sociedade norte-americana, ele passou a defender de maneira cada vez mais enfática que a conexão diferenciação-inclusão seria universal e, portanto, inespecífica às contingências históricas daquela experiência social. Já em "Evolutionary universals in society" [1964], artigo no qual o autor aprofunda seu diálogo com as teorias biológicas e cibernéticas, Parsons passa a considerar que a sociedade moderna em geral seria conformada por uma estrutura básica, que acompanharia a diferenciação de quatro universais evolutivos: mercados monetarizados, organização burocrática, sistema legal universalista e associação democrática. Uma vez institucionalizados, estes universais evolutivos aumentariam consideravelmente a capacidade adaptativa das sociedades, especialmente por serem capazes de processar níveis crescentes de complexidade social. No caso da associação democrática - que Parsons entende no registro usual da democracia representativa -, sua escolha como um evolutivo universal se deveria à sua capacidade única no sentido de mediar a legitimação do poder justamente através do pluralismo e da complexidade constitutivos de uma estrutura social moderna (Parsons, 1964c, pp. 355-356). Embora o autor, reivindicando Weber, reconheça que, em termos concretos, a institucionalização de cada um destes universais evolutivos teria sido resultado de um longuíssimo processo histórico, com avanços, retrocessos e combinaçôes contextuais nem sempre balanceados, o argumento encaminha-se inevitavelmente para a tese da convergência final de todas as sociedades modernas em torno desta configuração estrutural básica, na qual diferenciação e democratização são como duas faces da mesma moeda (Idem, p. 357).

Grosso modo, podemos dizer que Florestan Fernandes e Gino Germani seguiram um caminho inverso ao de Talcott Parsons. Se o último foi paulatinamente expurgando certa visada crítica e histórico-comparada típica de sua produção dos anos de 1940 em prol de uma concepção positiva e evolucionária da sociedade moderna - na qual a democracia figurava como um universal evolutivo e, logo, como potencialmente generalizável ${ }^{4}-$, os dois primeiros tiveram que trazer para o primeiro plano justamente as complicações de um processo de desenvolvimento periférico que, de modo cada vez mais nítido, se dissociava de padrões democráticos 
de integração social. Além disso, se Parsons pôde, como na noção de universais evolutivos, mobilizar a dimensão temporal numa longuíssima duração, esvaziando o poder explicativo das contingências históricas, Fernandes e Germani, cada um a sua maneira, passaram a incorporar de maneira decidida as especificidades de suas sociedades no cerne da teorização sociológica. Em outras palavras, estes dois sociólogos situados na periferia necessitaram adensar historicamente a análise a fim de captar a nota divergente da mudança social em contextos não clássicos de revolução burguesa. Daí que, na primeira metade da década de 1960 , eles tenham exprimido as complicações das sociedades brasileira e argentina através dos termos "dilema social brasileiro" e "paradoxo argentino". Essas duas noções, em vez de sugerirem um processo relativamente linear - como a noção de universais evolutivos mais ou menos insinua -, apontam antes para uma trajetória histórica problemática ou mesmo labiríntica.

A noção de dilema social brasileiro começou a ser empregada de maneira sistemática por Florestan Fernandes a partir do texto "Reflexões sobre a mudança social no Brasil” [1962], sétimo capítulo de $A$ sociologia numa era de revolução social [1963]. Em termos mais concretos, esta noção se vinculava às suas interpretações sociológicas do fracasso de dois movimentos sociais de caráter democratizante: a campanha em torno da escola pública e o associativismo no meio negro de São Paulo. Ambos os movimentos, na perspectiva do autor, teriam como objetivo ajustar a estrutura e o funcionamento da sociedade de classes no Brasil, em processo acelerado de diferenciação e expansão, aos seus fundamentos morais ou axiológicos. Para Fernandes, estes fundamentos seriam, entre outros, "a universalização e o respeito pelos direitos fundamentais da pessoa humana, a democratização da educação e do poder, [...] a consagração de modelos racionais de pensamento e de ação, [...] etc.” (Fernandes, 1979, pp. 322-323). Quer dizer: tanto a campanha quanto o movimento negro pressionariam no sentido de se universalizar uma ordem social competitiva. Por este último termo, Fernandes entende o princípio organizatório básico de uma sociedade de classes: caso esse tipo societário funcionasse à plena eficácia, isto é, promovendo ajustamentos racionais (definidos em termos dos fundamentos morais mencionados), a ordem social se abriria a todos os grupos sociais, sem estratificações de ordem extraeconômica (Cohn, 1986, p. 135). Dito de outra maneira, a competição pelas posições mais vantajosas da estrutura social não seria monopolizada por nenhum grupo social específico, ao contrário do que ocorreria numa ordem social estamental. Tanto a campanha quanto o movimento negro, nesta notação sociológica, teriam como bandeira exatamente a luta contra o privilégio - escolar ou racial - em prol da universalização dos direitos e das garantias sociais (Arruda, 2009; Bastos, 1987; Silva, 2012).

Seria o caso de, mais uma vez, como para Parsons, associar diretamente, no que tange à sociedade moderna (ou de classes, como prefere Fernandes), diferenciação e inclusão? Não necessariamente. Se, nos textos do sociólogo norte-americano, a conexão entre aqueles dois termos é vista de maneira naturalizada no registro de sua discussão dos universais evolutivos, no esquema de Fernandes, a articulação entre a expansão da sociedade de classes e a universalização da ordem social competitiva opera em chave contrafactual, tensionando o próprio andamento da análise. Explico-me melhor. Os dois termos se articulariam se a sociedade de classes operasse em sua eficácia-limite, ou em sua racionalidade máxima, ajustando as práticas sociais concretas aos valores básicos da ordem social. Como fica patente em suas análises da campanha e do movimento negro, a derrota das opçôes democratizantes revelaria a persistência de ajustamentos irracionais que, em vez de promoverem o ajuste entre a sociedade de classes no Brasil e seus fundamentos morais, tornariam permanente a inconsistência entre práticas sociais e valores. Este seria o núcleo do dilema social brasileiro: "um tipo de inconsistência estrutural e dinâmica que nasce da oposição entre o comportamento social concreto e os valores básicos de determinada ordem social" (Fernandes, 1976, p. 208). $\mathrm{Ou}$, noutras palavras, a sociedade brasileira seria incapaz de dar concretude - ou saturação empírica, como diria Fernandes - às promessas emancipatórias inscritas na sociedade de classes, apegando-se a práticas e orientações arcaicas e/ou egoístas a despeito das inconsistências que isto geraria no próprio padrão de integração social. ${ }^{5}$ 
A fim de clarificar o argumento do autor, vejamos como ele avalia os descaminhos da campanha no seguinte trecho:

Em quase cinco dezenas de debates, [...] consegui estabelecer um diálogo, por vezes de natureza polêmica, com representantes dos diferentes círculos da sociedade brasileira contemporânea. [Cheguei] a conclusōes sumamente penosas e inesperadas. Nós nos modernizamos por fora e com frequência nem o verniz aguenta o menor arranhão. $E$ uma modernidade postiça, que se torna temivel porque nos leva a ignorar que os sentimentos e os comportamentos profundos da quase totalidade das pessoas cultas se voltam contra a modernização (Idem, p. 205, grifos nossos).

Este quadro, que apresenta uma espécie de modernidade sui generis no Brasil, é o desdobramento de dois argumentos principais. $\mathrm{O}$ primeiro refere-se ao caráter puramente epidérmico ou compensatório da adesão, sobretudo nos círculos sociais dominantes, aos fundamentos morais da sociedade de classes. Apesar de verbalmente afinados com os valores modernos e democráticos, essa racionalidade aparente dos segmentos cultos da sociedade brasileira encobriria uma irracionalidade de fundo uma espécie de superego nacional (Idem, p. 210) altamente reativa a quaisquer transformaçóes substantivas na distribuição da renda, do poder e do prestígio social. Nos termos de Fernandes:

O comportamento pode manter-se fiel a modelos arcaicos e tradicionalistas; a verbalização que dele faz o homem eleva-se a outro nível, como se o agente social fosse guiado por outros incentivos e motivaçōes. Daí toda uma mitologia do progresso, da modernização tecnológica e do liberalismo, que condensa uma infinidade de manifestaçôes simbólicas compensatórias, cuja função é sempre a mesma: dar-nos segurança no plano da afirmação coletiva de comunidade nacional (Idem, p. 209).

Esta inconsistência entre a persistência de práticas arcaicas e a adesão (superficial) a valores modernos e democráticos parecia indicar que, no Brasil, os valores seriam incapazes de funcionar como instância última de controle na direção das mudanças estruturais, como diria Parsons (1974) em sua apropriação da noção de hierarquia cibernética. Ou, melhor dito, que a introdução de valores ajustados à sociedade de classes não seria suficiente, por si só, para efetivamente levar a cabo a democratização do sistema social. Daí o segundo argumento de Fernandes: em vez de um padrão de mudança progressivo, linear, assistiríamos à emergência de um padrão sociopático, uma espécie de "resistência residual ultraintensa à mudança social" (Fernandes, 1976, p. 211, grifos no original), conferindo-lhe um caráter limitado ou mesmo conservador. Por esta razão, Fernandes diz que o sentido da mudança social não é automático, isto é, não se encaminharia necessariamente para a universalização da ordem social competitiva. O crucial seria a avaliação sociológica da qualidade da mudança social, definida mediante o modo pelo qual os grupos sociais em disputa selecionam ou neutralizam os influxos construtivos da expansão da sociedade de classes. No caso brasileiro, como assinala o próprio autor, "o fulcro dinâmico da configuração do equilíbrio social não provém das forças sociais inovadoras" (Idem, ibidem), posto que os círculos sociais dominantes "só aceitam as inovações que não modificam a estrutura da situação e suas perspectivas de desenvolvimento" (Idem, p. 207).

Essa proposiçãa, feita à luz da derrota das opçôes democratizantes que poderiam dissolver o dilema social brasileiro, foi sendo desdobrada em vários constructos conceituais, até atingir certa cristalização teórica com a noção de capitalismo dependente em fins da década de 1960, como veremos na próxima seção. Contudo, a própria noção de dilema, tal como expusemos aqui, já apontava de maneira clara para a importância explicativa das especificidades históricas da sociedade brasileira, cujo padrão de desenvolvimento parecia combinar arcaísmo e modernidade em vez de expurgar o primeiro com a expansão da última. Se compararmos as conclusões de Fernandes sobre a precária integração do negro em São Paulo com as expectativas positivas de Parsons a respeito da plena cidadania dos negros nos Estados Unidos, a distância não po- 
deria ser maior. Em vez de uma linha reta, a sociedade brasileira percorreria uma trajetória sinuosa, com reposiçóes estruturais de elementos legados do passado estamental:

Como se fosse uma hidra, a desigualdade racial se recupera a cada golpe que sofre. Onde os interesses e os liames das classes sociais poderiam unir as pessoas [...], fora e acima das diferenças de raça, ela divide e opõe, condenando o negro a um ostracismo invisível e destruindo, pela base, a consolidação da ordem social competitiva como democracia racial (Fernandes, 2008, pp. 570-571, grifo no original).

Nos textos de Germani, a exploração teórica da conexão entre sociedade moderna e democracia também é decisiva, operando, porém, em registro distinto. Se tanto Parsons quanto Fernandes elaboram, cada um a seu modo, a ideia de que um padrão de integração social democrático estaria inscrito (ainda que potencialmente) na experiência moderna, Germani, por sua vez, retém o melhor de sua atenção na análise de como certas trajetórias sócio-históricas de modernização, ao contrário, tornariam mais verossímeis as soluções autoritárias. Nesse sentido, desde os seus primeiros esforços de teorização sobre a mudança social, Germani insiste no seguinte argumento: os processos tardios de modernização, comparativamente mais acelerados e assincrônicos - isto é, alguns subsistemas sociais se adiantariam mais do que outros na adoção de pautas modernas, especialmente a esfera econômica que as experiências pioneiras de passagem à modernidade, poderiam acarretar tensōes agudíssimas, com resultados políticos muitas vezes inesperados. ${ }^{6}$

Esta proposição teórica de Germani, acionada de modo esquemático na primeira parte de Politica y sociedad en una época de transición social [1962], prende-se claramente aos esforços do autor - e de toda a intelectualidade argentina da época, poderíamos dizer (Sarlo e Altamirano, 2007) - em elucidar o sentido do peronismo. Embora Germani não subsumisse a adesão das classes populares argentinas a Perón a uma experiência fascista, associação recorrente no debate da época, parecia-lhe claro que se tratava de uma solução de caráter autoritário, sem as mediações democráticas que teriam presidido, a seu ver, a participação política operária em certos países europeus (Germani, 1956). Ora, como explicar que isto tenha ocorrido na Argentina, onde justamente, segundo Germani, o processo de modernização teria avançado mais que em qualquer outro país latino-americano? Esta dissociação entre modernização - que, no caso da Argentina, apresentava índices que a colocavam "muito próxima [...] aos países mais avançados" (Germani, 2006, p. 242) - e democratização estaria na raiz daquilo que o autor chamou de paradoxo argentino.

O termo paradoxo, aqui, não é fortuito. Os mesmos processos que teriam feito da Argentina uma sociedade relativamente modernizada, na esteira do boom agropecuário de fins do século XIX até meados da década de 1920 , teriam concorrido também para os inúmeros problemas por ela enfrentados nos anos de 1950-1960. Ou, como expôs no artigo "La Argentina: desarrollo económico y modernización" [1963], não seria o atraso, mas o adiantamento da modernização social - altos índices de urbanização e de escolarização, grandes classes médias, elevadas taxas de mobilidade social etc. -, vis-à-vis um desenvolvimento industrial apenas incipiente, o principal impasse da sociedade argentina. $O$ "padrão exitoso estabelecido durante o período de prosperidade" (Germani, 2006, p. 248), assinala o autor, teria assegurado a "vastos estratos da população certa participação no modo de vida urbano e nos bens materiais e não materiais da sociedade moderna" (Idem, p. 246). E este sucesso na integração dos atores sociais modernos que a expansão econômica ia criando - especialmente classes médias, industriais e operários - teria roubado, no mesmo passo, o seu potencial transformador, já que diminuiria "o elemento de desafio suficientemente dramático capaz de despertar [...] as energias necessárias para introduzir inovaçôes substanciais" (Idem, pp. 249-250, grifos no original).

Em termos mais concretos, Germani introduz na análise uma série de especificidades históricas da sociedade argentina que teria contribuído para esta espécie de timidez transformadora de seus atores sociais modernos. Por um lado, o fato de que a expansão dos setores médios e do operariado urbano no início do século xx tenha sido 
praticamente monopolizada por estrangeiros, na esteira da grande imigração ultramarina que alterou radicalmente a estrutura social do país. Os efeitos políticos desta situação seriam marcantes: "em termos eleitorais, isto significava" que "entre $50 \%$ e $70 \%$ dos habitantes se encontrava à margem de seu exercício legal" (Germani, 1965, p. 220). Alijados da competição eleitoral, as possíveis consequências democratizantes da presença dos imigrantes nos setores dinâmicos da economia urbano-industrial em expansão teriam sido diluídas, o que explicaria inclusive, segundo Germani, por que o radicalismo - movimento político nucleado na Unión Cívica Radical (UCR), que governou a Argentina entre 1916 e 1930 - acabou não usando "o poder para aportar as transformaçōes na estrutura social que teriam assegurado uma base mais segura para o funcionamento das instituiçóes democráticas". Como exemplos da limitação do radicalismo, neste particular, o autor assinala que "a estrutura econômico-social do campo permaneceu praticamente inalterada", e que os "parlamentos radicais mantiveram a legislação repressiva criada pela oligarquia no começo do século diante da primeira expansão dos movimentos operários" (Idem, pp. 222-223). Por outro lado, a experiência vertiginosa de ascensão social vivida por estes mesmos imigrantes terminaria por dificultar a formação de solidariedades estáveis de classe, cruciais - como mostraria a experiência europeia - para a emergência de partidos políticos de esquerda e de orientação democrática. Vejamos como o autor divisa os efeitos desta fluidez da estrutura social argentina, tal qual demonstrada num extenso survey realizado por ele e sua equipe na Grande Buenos Aires:

A experiência reiterada, durante 60 ou 70 anos, pelos imigrantes estrangeiros e seus filhos, de uma sociedade aberta, unida ao grande intercâmbio entre classes, foi provavelmente um fator muito importante no sentido de impedir que o processo de urbanização e a constituição de um proletariado industrial originassem movimentos de massa orientados ideologicamente à esquerda. [...] Houve, na verdade, movimentos deste tipo, mas não tiveram efeitos políticos duradouros; por um lado, estavam formados por estrangeiros que careciam de direitos políticos; por outro, eles próprios e seus descendentes não permaneceram tempo suficiente na condição operária a fim de dar estabilidade e continuidade a organizações ideologicamente orientadas de acordo com a esquerda clássica (Germani, 1963, p. 363).

Portanto, em que pese o reconhecimento da importância da imigração ultramarina na modernização da estrutura social argentina, Germani não deixa de atentar para as suas limitações no sentido de "criar um marco institucional para o funcionamento sem tropeços de um regime representativo a um nível de participação total" (Germani, 1965, p. 240). Assim, o que está em jogo, em termos explicativos, é a identificação de uma determinada sequência histórica cujas consequências repercutiriam de modo altamente problemático nas décadas seguintes, marcadas por um novo movimento migratório de massa do interior argentino (e demais países limítrofes) à metrópole portenha. $\mathrm{Na}$ ausência de canais representativos democráticos, nos meios operários, fortes o suficiente para absorver a nova massa populacional abruptamente deslocada para o mundo urbano-industrial, apenas o peronismo teria logrado conferir expressão política a estes segmentos recém-mobilizados:

Estas grandes massas transplantadas de maneira rápida às cidades, transformadas abruptamente de peões rurais em operários industriais, adquiriram significação política sem que ao mesmo tempo houvesse os canais necessários para a sua integração ao funcionamento normal da democracia. A política repressiva dos governos desde o final do século passado, [...] unida à ausência de partidos políticos adequados aos seus sentimentos e necessidades, deixavam estas massas em disponibilidade, faziam delas elemento disponível para ser aproveitado para qualquer aventura que lhes oferecesse alguma forma de participação (Idem, pp. 225-226).

Como dissemos, Germani sempre diferenciou claramente o peronismo das experiências fascistas na Europa. E isto por dois motivos principais: (a) 
devido à diversa base social dos dois movimentos de extração popular e operária, no peronismo, e classes médias em risco de proletarização, no fascismo -, e (b) no que tange à maior racionalidade do primeiro em face do segundo. Para o autor, a despeito de sua orientação geral autoritária, o peronismo teria conseguido fazer valer vários tipos de liberdades concretas para as classes populares argentinas, como "participar em uma greve", "eleger um representante sindical" ou mesmo "discutir em pé de igualdade com o patrão" (Germani, 1962, p. 39). No entanto, assim como o radicalismo não teria atuado em seu contexto no sentido de promover mudanças estruturais, também o peronismo teria ficado muito aquém de suas potencialidades transformadoras. Além do aspecto autoritário do movimento, fazendo com que as classes populares conhecessem "somente um ersatz de participação política", isto é, uma "participação ilusória" (Germani, 1965, pp. 226-227), a velocidade da mobilidade ascendente experimentada pelos antigos trabalhadores rurais ao chegarem a Buenos Aires conformando uma nova classe operária - igualmente teria refreado o ímpeto anti-status quo:

Ao darem apoio ao peronismo, [as classes populares] escolhiam uma alternativa moderada: [...] o peronismo foi muito mais cauteloso que a maior parte dos movimentos deste tipo. Nunca questionou a base da ordem socioeconômica existente [...]; apenas insistiu na justiça social, na legislação social, na industrialização, na reforma agrária e no planejamento e em outras mudanças compatíveis com os interesses de alguns setores das classes médias (Germani, 1969, pp. 118-119).

Estes seriam os argumentos principais de Germani em sua tentativa de elucidar o paradoxo argentino. Vimos que, a fim de entender a conexão entre modernização e experiência autoritária, na Argentina, o autor precisou introduzir em sua teorização uma série de especificidades históricas, notadamente no que se refere à sequência histórica radicalismo-peronismo, índices do caráter limitado da ação transformadora dos seus principais atores sociais modernos. Nesse sentido, contra Parsons - e tam- bém contra Seymour Lipset, com quem Germani manteve importante interlocução (Amaral, 2009) -, a acelerada modernização da sociedade argentina não parecia fortalecer instâncias democráticas de integração social, mas justamente o oposto. "A profunda crise política que afeta o país há mais de 30 anos", assinala o autor, "constitui um verdadeiro enigma para os estudiosos da sociologia do desenvolvimento econômico" (Germani, 1965, pp. 206-207).

\section{As partes e o todo}

$\mathrm{Na}$ seção anterior, contrastamos as formulaçōes de Parsons, Fernandes e Germani sobre a conexão entre desenvolvimento e democracia - os termos específicos variam de autor para autor - feitas na primeira metade da década de 1960 . De modo esquemático, argumentamos que haveria um caminho inverso na teorização realizada no centro e nas periferias. Nos textos de Parsons, tal conexão foi crescentemente articulada em chave naturalizada, como se a expansão da sociedade moderna pudesse, mesmo que a longo prazo, gerar os mesmos efeitos independentemente das especificidades históricas de cada sociedade. Já nos textos de Fernandes e Germani, embora de modos muito diferentes, teriam sido justamente os aspectos especificos às sociedades brasileira e argentina, respectivamente, as principais componentes explicativas no que toca à dissociação entre desenvolvimento e democracia nestes contextos sócio-históricos.

Agora, passaremos a delinear brevemente os principais constructos teóricos destes três autores a partir de fins da década de 1960, quando este deslocamento reciproco entre as teorizações feitas no centro e nas periferias ganha clareza, sistematicidade e generalidade. Nos livros The system of modern societies [1971] e American society [2007], de Parsons, Sociedade de classes e subdesenvolvimento [1968] e A revolução burguesa no Brasil [1975], de Fernandes, e La sociología de la modernización [1969] e Authoritarianism, fascism and national populism [1978], de Germani, os três autores procuram articular teoricamente as especificidades de suas próprias sociedades com a expansão mundial do tipo moderno de sociedade. Dito de outro modo, nestes livros os au- 
tores teorizaram sobre a marcha do moderno em geral, e não somente sobre os Estados Unidos, Brasil e Argentina, ainda que as referências a estas sociedades tenham sido intensamente mobilizadas pelos três. Ora, se Parsons já ensaiava algo nesse sentido há algum tempo, Fernandes e Germani apenas conseguem dar este passo com alguma consistência na segunda metade da década de 1960, o que não é de somenos. Afinal, captar teoricamente o dinamismo da sociedade moderna como um todo a partir de posiçôes periféricas, extravazando a análise para além de seu contexto sócio-histórico imediato, é produto ainda escasso na teoria sociológica.

Em primeiro lugar, vejamos de que maneira Talcott Parsons articulou as especificidades de sua sociedade de referência ao movimento mais geral da sociedade moderna. No artigo "Comparative studies and evolutionary change" [1970], o autor afirma que o entendimento do peculiar dinamismo societário dos Estados Unidos seria inviável sem uma "perspectiva comparada e evolucionária" (Parsons, 1971, p. 139). Nesse sentido, em vez de analisar a sociedade norte-americana de maneira isolada, seria mais profícuo entender suas especificidades à luz do sistema das sociedades modernas, isto é, no interior do conjunto mais amplo de experiências modernas - que, cada vez mais, englobavam quase todas as formas sociais existentes. Por esta razão, o uso do plural para designar o sistema das sociedades modernas não seria casual:

O uso da forma plural da palavra sociedade do título [The system of modern societies] é deliberado e possui importância central. É claro que podemos nos referir, com sentido, à sociedade moderna como um tipo, mas não acho que possa ser útil aos sociólogos tratar a União Soviética, a Grā-Bretanha, os países escandinavos e os Estados Unidos - para citar alguns dos mais importantes - como constituindo uma sociedade. Mas, se há muitas, isto não implica que suas diferenças sigam um padrão de variação aleatória, explicada em cada caso por "histórias" singulares (Idem, p. 108, grifo no original).

A peculiar junção de singular - o sistema - e plural - das sociedades modernas - no título do li- vro de Parsons revela bastante de sua orientação mais geral: captar o máximo de variação possível nas estruturas das sociedades modernas existentes, mas sem dissolver a ideia de que elas, em conjunto, conformariam um único tipo. Disso decorre a sua compreensão de que estas variaçōes não seriam o resultado de simples histórias singulares, mas conformadas pela própria diferenciação sistêmica ao longo de todo o sistema em escala mundial. De acordo com o autor, as diferenças fundamentais entre as sociedades modernas "parecia[m] se encaixar perfeitamente num padrão de quatro funçôes" (Idem, p. 108), ou seja, não só no interior de cada sociedade mas também no sistema das sociedades modernas assistiríamos às grandes linhas de diferenciação sistêmica indicadas pelo esquema agil. É como se cada sociedade moderna importante tivesse se especializado na diferenciação máxima de um subsistema, contribuindo para o aumento da complexidade geral do sistema intersocietário moderno. Para ficarmos nos exemplos do autor: os Estados Unidos dariam mais peso à função adaptativa (a) - sistema econômico -; a União Soviética, à função goal-attainment (g) - sistema político -; a Inglaterra, à função integrativa (i) - comunidade societária -; e a França e a Alemanha, à função latent pattern-maintenance (l) - sistema cultural (Idem, pp. 108109). Encaixando as especificidades nacionais sempre nalgum nicho funcional determinando, é assim que o autor explica o poderio econômico norte-americano diante da burocratização da sociedade soviética, ou o desenvolvimento de direitos sociais na Inglaterra em contraposição à pujança da produção cultural francesa e alemã.

Retomando o argumento mais geral formulado em "Evolutionary universals in society" [1964], Parsons considera que o desenvolvimento do sistema das sociedades modernas seria resultado de um processo de longa duração, dramatizado no terreno histórico por três revoluçóes, que expressariam as contínuas diferenciações sistêmicas. As duas primeiras revoluçōes - a industrial e a democrática, ocorridas na Europa Ocidental (na Inglaterra e na França, respectivamente) - teriam diferenciado, por um lado, o sistema econômico (a) do sistema político (g) e, por outro, estes dois subsistemas da comunidade societária (i). Embora, para Parsons, 
a sociedade norte-americana não tenha protagonizado nenhuma destas duas revoluçôes, ele afirma que, já "na época da visita de Tocqueville", teria se realizado ali "uma síntese da revolução francesa e da inglesa" e, mais ainda, que "os Estados Unidos tinham constituído uma sociedade tão democrática quanto todos [...] tinham desejado”. Não por acaso o autor diz que esta sociedade passaria a desempenhar, a partir de então, "um papel [...] comparável ao da Inglaterra no século XVII" (Parsons, 1974, p. 108). Se a Europa ainda se via às voltas com o seu passado de distinções estamentais e clivagens classistas muito rígidas, a sociedade norte-americana já teria superado esses problemas desde o início de sua formação (Idem, pp. 111-112).

Passando a ocupar, assim, a vanguarda do sistema da sociedade moderna, caberia agora aos Estados Unidos liderar a terceira revolução, qual seja, a revolução educacional. Para Parsons, com a expansão em larga escala do ensino superior em meados do século XX, assistiríamos à diferenciação final entre o sistema cultural (l) e a comunidade societária (i), isto é, à institucionalização de um complexo cognitivo no sistema social, com os seus concomitantes efeitos na secularização da cultura e no padrão de integração social (Parsons e Platt, 1973). Além de representar o fim da linha de um longo processo de constituição de uma "comunidade societária que não se baseia diretamente na religião" (Parsons, 1974, p. 124), a revolução educacional radicalizaria o caráter democrático da sociedade moderna. Isto ocorreria porque, com a universalização do acesso ao ensino, as principais formas de estratificação social estariam associadas a imperativos unicamente funcionais, e não mais a critérios particularistas:

O foco da nova fase é a revolução educacional que, em certo sentido, sintetiza os temas da revolução industrial e da democrática: igualdade de oportunidade e igualdade de cidadania. Já não se supõe a capacidade inata do indivíduo [...]. Ao contrário, reconhece-se que a estratificação por capacidade é mediada por uma complexa série de [estágios] no processo de socialização. Cada vez mais, existem oportunidades para que os relativamente desfavorecidos consigam vencer [nos processos de] seleção, [rigidamente regulamentados] por normas universalistas (Idem, p. 119).

Em suma, na narrativa histórica parsoniana, a posição de vanguarda ocupada pela sociedade norte-americana no sistema intersocietário moderno seria muito mais consequência de seu avanço inaudito no sentido de diferenciar uma comunidade societária amparada em critérios universalistas que do seu poderoso complexo industrial-militar, explicação que ele considera reducionista e equivocada (Idem, p. 141). Esta especificidade histórica, no entanto, até mesmo pela posição de liderança dos Estados Unidos, seria naturalizada por Parsons em seu esquema cibernético-evolucionário, já que nela estaria contido o próprio sentido geral da mudança. Tendo em vista a posição ocupada pelo sistema de pattern-maintenance (ou sistema cultural) na escala cibernética, os valores democráticos institucionalizados na comunidade societária norte-americana seriam capazes de se difundir por todo o sistema das sociedades modernas, pressionando por transformaçôes análogas, mesmo que a longuíssimo prazo, em todas as sociedades localizadas no interior do sistema:

[...] os valores sempre potencialmente [...] transcendem qualquer comunidade específica. [...] As forças e os processos que transformaram a comunidade societária dos Estados Unidos e prometem continuar a transformá-la não são peculiares a esta sociedade, mas penetram todo o sistema moderno - e modernizante. [...] Desse ponto de vista, a institucionalização intersocietária de um novo sistema de valores [...] se torna decisiva (Idem, p. 147, grifos no original).

Uma solução teórica deste tipo, como veremos a seguir, não emergiu dos textos de Florestan Fernandes e de Gino Germani. Ainda que salientando a posição específica dos Estados Unidos no interior do sistema das sociedades modernas, Parsons não considerou as contingências históricas dessa experiência social como uma componente explicativa fundamental de sua análise sociológica. Transferin- 
do, grosso modo, a conexão diferenciação-inclusão para o contexto de uma sociedade moderna de escopo mundial, é como se Parsons reduzisse o complexíssimo processo de conformação histórica da civilização ocidental à dinâmica social encapsulada no seu esquema agil, aplainando todas as arestas históricas encontradas pelo caminho. Esta robusta ordenação formal - alguns diriam formalista - do processo social teria que ceder espaço, nos textos de Fernandes e de Germani, a constructos de menor vigor ordenador, capazes de captar as asperezas de uma matéria social periférica arredia a conceituações demasiado ordeiras.

Comecemos com a noção de capitalismo dependente, de Fernandes. Se Parsons fez grande esforço para, a despeito de reconhecer a existência de enormes variaçôes estruturais, considerar as sociedades modernas como um único tipo, o autor de $A$ revolução burguesa no Brasil [1975], logo de saída, assinala a existência de dois subtipos fundamentais: a sociedade de classes conformada pelo capitalismo autônomo e a sociedade de classes conformada pelo capitalismo dependente. Não que estes dois subtipos fossem essencialmente distintos. O próprio autor ressalva que "o regime de classes é o mesmo", não invalidando "conceitos, métodos e teorias acumulados previamente". Contudo, a fim de se analisar sociologicamente o dinamismo do capitalismo dependente, teríamos que proceder, segundo Fernandes, a uma "verdadeira rotação ótica" (Fernandes, 1979, p. 25), sobretudo no que tange à utilização da noção de sistema. Esta noção, tal como empregada recorrentemente na teoria sociológica, somente apresentaria eficácia explicativa para os casos de capitalismo autônomo:

Ao estudar o regime de classes em sociedades nacionais dotadas, ao mesmo tempo, de desenvolvimento capitalista autônomo e de posição hegemônica nas relações capitalistas internacionais, os cientistas sociais puderam operar [...] com uma homogeneização máxima dos fatores [...] da diferenciação social; puderam concentrar a [...] análise [...] em casos extremos, considerados como sistema de uma perspectiva nacional, como se a economia, a sociedade e a cultura, sob o capitalismo, se determinassem apenas a partir de um núcleo interno em expansão; supuseram que os fatores causais e funcionais da transformação capitalista [...] atuam a partir de dentro [...] e variam, sempre, de um ponto de menor complexidade para outro de maior complexidade quanto ao grau de diferenciação [...] (Idem, ibidem, grifo nosso).

Embora seja verdade que Parsons tenha procurado dar conta de certo dinamismo intersocietário com a noção de sistema das sociedades modernas, o problema colocado por Fernandes parece caber-lhe inteiramente. Não que o ultimo rejeite a validade de uma perspectiva sistêmica. Ela apenas não conseguiria captar as conexōes fundamentais do capitalismo dependente ao abstrair, do campo de observação, a heterogeneidade de processos sociais que lhe imprimiriam sentido, especialmente a dupla articulação de elementos internos e externos à sociedade, por um lado, e de elementos arcaicos e modernos, por outro (Fernandes, 2006, p. 293). Assim, continua o autor, na periferia do capitalismo, os sociólogos teriam que operar com uma "heterogeneização máxima dos fatores propriamente estruturais de diferenciação social”, haja vista "[a] natureza e [a] variedade de forças que intervêm, concretamente, na configuração [...] do regime de classes das naçōes capitalistas heteronômicas". Estas forças seriam basicamente três: (a) "procedentes das sociedades hegemônicas externas", (b) "provenientes de tendências dominantes na evolução das estruturas internacionais de poder" e (c) forças "que nascem a partir de dentro, das próprias sociedades de classes dependentes" (Fernandes, 1979, p. 26). Como corolário desta rotação ótica proposta por Fernandes, é como se os sociólogos perdessem "parte de seu arbítrio na abstração do caso nacional do amplo conjunto de forças, que operam simultaneamente e com potencialidades [...] ao mesmo tempo tão variadas e contraditórias" (Idem, p. 27, grifo no original). Noutros termos, o autor avançou a ideia de que só seria possível entender as complicações do capitalismo dependente, de sua marcha histórica não linear, caso se empregasse certa perspectiva de totalidade.

A fim de se analisar este processo de mudança determinado por forças sociais tão contraditórias - 
por um lado, forças internas e externas pressionando pela expansão da sociedade de classes e da ordem social competitiva, por outro, forças internas e externas reforçando o legado do antigo regime e as orientaçóes estamentais a ele ligadas (Idem, pp. 3940) -, Fernandes indica a necessidade de se adensar historicamente a teorização. Não podendo subsumir o sentido geral do processo ao ritmo progressivo de um dinamismo interno em crescente diferenciação como em Parsons -, o autor mobiliza intensamente a matéria histórica brasileira como expediente explicativo, retendo a atenção em seus momentos cruciais. Momentos cuja reconstrução, iniciada em A integração do negro na sociedade de classes [1964] quando aponta para o esvaziamento do movimento abolicionista e para o sentido excludente da expansão da sociedade de classes no Brasil -, ganha enorme amplitude em $A$ revolução burguesa no Brasil [1975], livro no qual Fernandes percorre o extenso período que se inicia no processo de independência até chegar aos efeitos do golpe militar de 1964. Mas esta atenção cerrada às especificidades da sociedade brasileira significa que Fernandes não teria procurado fazer generalizaçōes teóricas para além dela? A resposta a esta pergunta, negativa, passa por seu argumento de que a sociedade de classes no Brasil seria uma espécie de tipo extremo do capitalismo dependente. ${ }^{7}$

Isto ocorreria não devido à maior consistência da experiência moderna no Brasil em face de outros países periféricos, mas à máxima heterogeneidade dos elementos constituintes de sua estrutura social. $\mathrm{Ou}$, noutras palavras, porque, segundo o autor, na sociedade brasileira estariam presentes "tanto os aspectos mais arcaicos quanto os aspectos mais modernos da estratificação social condicionada pelo capitalismo dependente" (Fernandes, 1975, p. 50), ou ainda, noutra notação, porque aí "a dependência é mais profunda e diferenciada e o subdesenvolvimento é mais desenvolvido" (Fernandes, 1981, p. 115, grifo no original). Embora não seja o caso de reconstituirmos o modo pelo qual Fernandes analisa a trajetória histórica da sociedade de classes no Brasil, três pontos de sua argumentação são fundamentais. De modo esquemático, eles se referem: (a) aos efeitos limitadores do padrão de desenvolvimento duplamente articulado - no qual grande parte do excedente econômico não é retido internamente, mas succionado para fora -, concorrendo para que se "mantenham, indefinidamente, estruturas socioeconômicas e políticas arcaicas ou semiarcaicas" (Fernandes, 2006, p. 356); (b) à deformação estrutural da ordem social competitiva gerada por este tipo de sociedade de classes que, além de não se universalizar, agravaria a concentração da renda, do poder e do prestígio social - a "eficácia da competição e do conflito na coordenação das relações de classe" se fechariam na pequena órbita das "classes médias e altas" (Fernandes, 1979, p. 37) -; (c) sintetizando esses dois pontos, ao estilo autocrático de revolução burguesa. Sobre isto especificamente, escreve Fernandes:

Aí, a Revolução Burguesa combina - nem poderia deixar de fazê-lo - transformação capitalista e dominação burguesa. Todavia, essa combinação se processa em condições econômicas e histórico-sociais específicas, que excluem qualquer probabilidade de repetição da história ou de desencadeamento automático dos pré-requisitos do [...] modelo democrático-burguês. Ao revés, o que se concretiza, embora com intensidade variável, é uma forte dissociação pragmática entre desenvolvimento capitalista e democracia; ou, usando-se uma notação sociológica positiva: uma forte associação racional entre desenvolvimento capitalista e autocracia (2006, p. 340, grifos no original).

Lembrando que autocracia não se confunde embora se associe em várias ocasiões - com autoritarismo, mas significa uma orientação privatista em relação ao poder (Cohn, 2001), a sociedade brasileira seria um tipo extremo do capitalismo dependente porque, nela, a dissociação estrutural entre sociedade de classes e democracia apresentaria clareza máxima, sobretudo após o golpe de 1964. Depois de esmiuçar estas especificidades históricas, Fernandes mostra que este padrão de desenvolvimento que é capaz, por um lado, de expandir de maneira considerável os dinamismos típicos de uma sociedade de classes, mas sem, por outro, expurgar o legado histórico do antigo regime e universalizar uma ordem social competitiva - a conexão diferen- 
ciação-inclusão ficaria confinada a circuito fechado, sem se generalizar por todo o sistema social - teria grande significação teórica para a sociologia. $\mathrm{O}$ "presente do Brasil", arremata o autor, "contém o futuro de outros países, que pertençam à periferia do capitalismo mundial e não possam encaminhar-se diretamente ao socialismo" (Fernandes, 2006, p. 259). Em suma, é como se, a partir das complicações históricas da sociedade brasileira, tratadas com grande minúcia ao longo de $A$ revolução burguesa no Brasil [1975], pudéssemos ganhar perspectiva analítica sobre o movimento de expansão da sociedade de classes como um todo (Bastos, 2002).

$\mathrm{Se}$, como vimos, Florestan Fernandes propõe que não se poderia analisar os dinamismos da sociedade de classes como se ela gerasse sempre os mesmos efeitos independentemente do tempo, do espaço e das trajetórias históricas - propondo, neste sentido, quebrar em dois o tipo (capitalismo autônomo e capitalismo dependente) -, Gino Germani, por sua vez, dissolve quase completamente a ideia de que poderíamos tomar certos casos concretos de modernização como típicos ou generalizáveis. Isto não quer dizer, é claro, que o autor não tenha se dedicado a teorizar, em chave mais abstrata, sobre os processos de mudança. Contudo, sua proposição mais geral a este respeito - sobre o caráter inextricavelmente assincrônico dos processos de modernização - coloca em primeiro plano justamente a importância explicativa das contingências históricas. Senão, vejamos:

Nossa primeira generalização é que a modernização ou o desenvolvimento não é balanceado. A mudança é assincrônica: os vários componentes da estrutura sociocultural não iniciam a sua transformação simultaneamente, não caminham à mesma velocidade e tampouco os vários processos seguem sequências idênticas. A transição total, fruto da aceleração ou desaceleração destes processos ou subprocessos, ou de retardamentos ou antecipações peculiares na sua sequência, é um fator altamente determinante na modernização. [...] Em razão das consequências do assincronismo [...], é muito difícil formular uma sequência universalmente válida de etapas (Germani, 1981, p. 18).
Embora, neste trecho, o autor radicalize a ideia de que, dados os aspectos específicos e contingentes de todo processo de mudança, não haveria sequências universalmente válidas, ele busca alguns elementos mais genéricos capazes de apoiar sua teorização. Por um lado, Germani não descarta inteiramente certo repertório cognitivo da sociologia da modernização, já que acredita que o uso de correlações estatísticas para a fabricação de índices de modernidade poderia favorecer procedimentos comparativos (Germani, 1969, pp. 2627). Por outro, ele se propõe a construir uma série de tipologias de transição capaz de agrupar algumas experiências afins e significativas de modernização. Na versão norte-americana de La sociología de la modernización [1969] [The sociology of modernization (1981)], ele chega a identificar oito tipos ou subtipos de padrões de modernização, dentre os quais se incluiria a América Latina, tratada por Germani (1981, pp. 37-47) em perspectiva de conjunto. A este respeito, a referência fundamental do autor é o texto "Las etapas del proceso de modernización en América Latina” [1969].

Apesar de o termo "etapas" sugerir um processo linear de mudança, ao fazermos um corpo-a-corpo com o argumento de Germani vemos que não é bem o caso. Antes, são aspectos contingentes que sobem à tona. Definindo as principais etapas a partir de marcadores externos às sociedades latino-americanas - etapa i, "descobrimento"; etapa ii, "revoluções francesa e norte-americana"; etapa iii, "impacto da revolução industrial” e da "emigração europeia em massa"; etapa iv, "grande depressão e segunda guerra mundial" (Germani, 1969, pp. 51-58) -, ele mostra, por exemplo, que se a simultaneidade destes impactos externos servia como suporte para a comparação entre os países, por um lado, estas mesmas forças, ao se combinarem com fatores endógenos específicos, teriam como "efeito habitual acentuar [as] descontinuidades internas, isto é, a assincronia entre áreas, instituiçôes, pautas de atitudes e comportamentos" (Idem, p. 37, grifos no original). Além disso, o autor é enfático ao afirmar que não opera com "um modelo puramente determinista de transição": os sentidos da passagem de uma etapa para outra seriam cronicamente dependentes da atuação de "indivíduos 
e grupos em posições-chave" (Idem, p. 28), o que poderia levar tanto à "interrupção da modernização" quanto ao "progresso em direção a graus de modernização social ou política mais elevados" (Idem, p. 29). Pouco se detendo sobre as duas primeiras etapas de modernização na América Latina, Germani concentra o melhor de sua atenção na passagem da etapa iii à etapa iv, dramatizada, historicamente, pela passagem do modelo agroexportador à economia urbano-industrial na região. Ainda que não seja o caso de reconstruirmos todo o argumento do autor a este respeito, algumas considerações são necessárias.

É digno de nota que, a fim de captar o caráter não linear da mudança, Germani tenha lançado mão sistematicamente do seguinte par conceitual: efeitos modernizadores-mecanismos estabilizadores. Mediante esses termos, seria possível explicar por que certos atores ou estruturas sociais responsáveis por um maior avanço na modernização durante a terceira etapa poderiam atuar como mecanismos de estabilização do processo na quarta etapa. O caso mais conspícuo, segundo o autor, seria o das classes médias: apesar de sua orientação progressista no sentido de ampliar os canais democráticos num primeiro momento, com a explosão da migração rural-urbana (consequência da própria industrialização) ela acabaria muitas vezes combatendo a extensão da participação política aos grupos recém-mobilizados. Noutras palavras, "as classes médias, ou parte delas, deixaram de ser fatores de mudança para a modernização e se converteram em fatores de estabilização" (Idem, p. 40). Mas a complexidade do quadro não se detém aí. A conexão entre fatores internos e externos às sociedades latino-americanas também poderia provocar antes o estancamento do que a continuidade da modernização:

Também intervieram outros fatores, exógenos e endógenos, que complicaram de modo singular a situação, adicionando novas rigidezes e levando em muitos casos ao estancamento ou à regressão no desenvolvimento econômico e na modernização política. Entre tais fatores devemos mencionar: (a) os resíduos sobreviventes, mas ainda ativos, das antigas estruturas de poder [...]; (b) as limitações das burguesias nacionais para exercer uma ação coerente e eficaz em favor do desenvolvimento econômico; (c) a persistência do intervencionismo militar. [...] [Entre] os fatores exógenos operantes em todos os aspectos, desde 1930, os mais importantes foram, sem dúvidas, as tensões criadas pela guerra fria e pelo poder hegemônico dos Estados Unidos. [...] É difícil colocar em dúvida que setores poderosos da sociedade norte-americana tenderam a reforçar as rigidezes mantidas por fatores internos, em oposição às forças favoráveis à introdução de reformas realmente significativas (Idem, p. 41).

Algum tempo depois, este esquema teórico ganharia aprofundamento e maior consistência teórica em Authoritarianism, fascism and national populism [1978], livro no qual Germani retoma a análise da sociedade argentina. Realizando uma exploração de longa duração de suas especificidades históricas - desde a independência até a crise do ciclo peronista dos anos de 1970 -, além de análises comparativas com sociedades europeias problemáticas, como Espanha e Itália, o autor leva às últimas consequências o princípio de que as contingências históricas deveriam ser acionadas como expediente explicativo da modernização. Ao definir, mais uma vez, o seu conceito de mudança social como não determinista, assinala:

No nível macro, a mudança pode ser concebida como um conjunto de processos [...] cuja convergência, num momento histórico definido, [...] pode produzir novas (parciais ou totais) formaçôes socioculturais (uma ou mais instituiçôes, grupos sociais, subsistemas inteiros ou um novo tipo de estrutura social global). [...] [A] combinação peculiar [destes] componentes é resultado [...] da natureza, ritmos e sequências de cada processo particular - e muito frequentemente também dos eventos traumáticos produzidos por súbita aceleração e/ou desaceleração destes processos ou por causas acidentais. (Acidentais são os eventos ou processos que não podem ser explicados somente com base nos fatores e nas variáveis considerados na análise) (Idem, pp. ix-x, grifos no original). 
Além de não determinista, o esquema teórico de Germani acaba multiplicando os fatores - desde causas macroestruturais até eventos acidentais - e os níveis de análise - de curto, médio e longo alcance (Idem, p. 5) -, todos igualmente relevantes para o entendimento do sentido dos processos de modernização. E, efetivamente, no andamento do livro, sua análise da sequência histórica radicalismo-peronismo ganha vários refinamentos, conjugando dados estruturais e conjunturais específicos - estes últimos vão ao extremo do detalhe histórico ${ }^{8}$ - na explicação do caráter mais disruptivo, em termos políticos, do segundo em relação ao primeiro.

A despeito desta visada atenta aos aspectos mais contingentes do processo social - em máximo contraste, portanto, com grande angular usada por Parsons -, Germani não deixa de salientar a existência de tendências mais gerais a todas as sociedades modernas. Em Authoritarianism, fascism and national populism [1978], retomando certas proposições com que vinha trabalhando desde a década de 1940, o autor ressalta como o processo de secularização, que constitui o dinamismo típico da sociedade moderna, nem sempre se conectaria a um padrão democrático de integração social. Entendendo secularização como a extensão de um tipo de ação eletiva - isto é, amparada no princípio da escolha - a todas as esferas sociais, incluída aí a esfera dos valores, Germani chama a atenção para a existência de uma "tensão estrutural inerente a todas as sociedades modernas": a tensão "entre secularização crescente e a necessidade de se manter um núcleo central prescritivo suficiente para a integração" (Idem, p. 7). Dito de outro modo, a secularização, por sua própria lógica expansiva, poderia pôr em questão o próprio núcleo normativo moderno, baseado historicamente nos ideais de igualdade, liberdade e autonomia. Nos termos do autor:

Mesmo este núcleo central, no entanto, pode ser mudado; neste caso, devem existir mecanismos capazes de realizar tais mudanças sem levar à destruição da própria sociedade. Desta condição básica emerge um fator potencial (no nível de máxima generalidade) para o surgimento do autoritarismo no sentido moderno.
[...] Soluções autoritárias são possíveis - e, em certas condiçôes, prováveis - em qualquer crise gerada pelas tensóes estruturais inerentes à sociedade moderna (Idem, pp. 7-8).

Mesmo que o autor localize a proposição quanto à compulsão autoritária da modernidade num nível de máxima generalidade - a explicação do fenômeno autoritário dependeria ainda de "condicionantes situados em níveis de médio e curto-alcance" (Idem, p. 8) -, a distância de sua teorização vis-à-vis a de Parsons, neste aspecto, é máxima. Ao contrário da tese exposta em The system of modern societies [1971], o sistema normativo, ou melhor, os valores modernos, não teriam nem estabilidade histórica, nem seriam capazes de funcionar como instância última de controle das mudanças. Para Germani, o risco sempre iminente de implosão do núcleo normativo moderno - dada a lógica expansiva da secularização - tornaria o autoritarismo uma síndrome intrínseca à modernidade. Neste registro sociológico, o paradoxo argentino, tal como discutido pelo autor na primeira metade da década de 1960 - uma sociedade altamente modernizada convivendo permanentemente com o espectro do fechamento político -, não seria simples exceção, mas uma possível exemplificação dos dinamismos inerentes à sociedade moderna.

\section{Consideraçóes finais: do assunto à forma}

Neste trabalho, procuramos mostrar em que medida a tradução de um produto intelectual - a sociologia da modernização - envolve operaçôes complexas e resultados muitas vezes inesperados. Mesmo em autores explicitamente dedicados a uma teorização em registro estrutural-funcionalista, caso de Florestan Fernandes e de Gino Germani, o envolvimento intenso e paciente de ambos com as complicaçóes da matéria social brasileira e argentina, respectivamente, foi deslocando de maneira cada vez mais nítida seus esquemas analíticos em relação aos pressupostos da matriz teórica "importada". Daí a relevância, para a demonstração desta hipótese mais geral, da recuperação da produção de Talcott Parsons 
como caso de controle das comparaçóes. A tradução, portanto, enquanto processo cumulativo poderíamos remontá-la, grosso modo, desde as pesquisas empíricas realizadas pelos autores nos anos de 1940-1950 (Brasil Jr., 2010) -, não implica simples readequação do referencial teórico importado ao novo contexto socio-histórico. Ao contrário, sobretudo quando criativa e relativamente bem-sucedida, a tradução leva a modificações profundas na própria estruturação dos trabalhos. $\mathrm{Ou}$, melhor dizendo, as especificidades históricas de suas sociedades deixam de ser simples assunto para se transformarem, nas sínteses teóricas de Fernandes e Germani que acabamos de discutir, em forma da teorização.

Esta passagem do assunto à forma significa que algo do ritmo social específico a estas sociedades passou a informar o princípio mais geral de intelecção do social construído pelos autores. De modo mais ou menos contraintuitivo, podemos afirmar que é justamente quando Fernandes e Germani procuraram explicitar a dinâmica do mundo moderno em geral, generalizando teoricamente para além de suas sociedades de referência, que podemos localizar melhor a maneira pela qual ambos internalizaram na forma as especificidades das sociedades brasileira e argentina. ${ }^{9}$

Por um lado, e em crescente contraste com as formulações de Parso ns, tanto Fernandes quanto Germani foram abrindo espaço explicativo para as contingências históricas do processo de mudança social. Em vez de encaminharem a discussão em registro evolucionário - vimos que Parsons, apesar de incorporar a dinâmica histórica em suas formulaçôes tardias, acabou retirando do campo de visão justamente as dimensões mais contingentes -, os dois autores foram sendo levados a compatibilizar o estrutural-funcionalismo com uma espécie de sociologia histórico-comparada. Quer dizer: tendo em vista os impasses divisados nos termos do dilema social brasileiro e do paradoxo argentino - tratados na primeira parte deste trabalho -, Fernandes e Germani foram forçados a tirar consequências teóricas da constatação de que a expansão da sociedade moderna não geraria os mesmos efeitos sociais independentemente das trajetórias sociais especificas a cada sociedade. Por outro lado, e também em direção contrária ao último Parsons, ambos questionaram a ideia de que a sociedade moderna traria inscrita em seus dinamismos um padrão democrático de integração social. Chamando a atenção para certas especificidades de seu funcionamento na periferia, mostraram que o oposto seria muito mais provável.

Estas aproximações entre as soluções teóricas de Fernandes e Germani, bem como os seus distanciamentos recíprocos diante dos constructos de Parsons, não devem apagar, porém, suas diferenças. Afinal, podemos tomar a noção de capitalismo dependente e a discussão em torno do caráter assincrônico da modernização como intercambiáveis? Para responder a esta questão, basta compararmos o maior nível de generalização suportado pelo constructo de Fernandes vis-à-vis a radicalização da dimensão contingente nas formulações de Germani. Retomando rapidamente o problema, lembremos que, para o primeiro, a sociedade brasileira seria um caso estratégico para a análise do capitalismo dependente. Dada a sua heterogeneidade estrutural máxima, os atributos deste tipo de sociedade de classes nela "aparecem com maior intensidade, precocidade e luminosidade" (Fernandes, 1975, p. 49). Já para Germani, ainda que a sociedade argentina pudesse exemplificar a compulsão autoritária intrínseca à sociedade moderna, a explicação sociológica não poderia deixar de considerar os aspectos históricos mais específicos - como acelerações ou desaceleraçôes abruptas de determinados processos de mudança por causas acidentais ou não - a fim de explicar o porquê de o autoritarismo se apresentar mais frequentemente em certos momentos e contextos sociais do que em outros. ${ }^{10}$

Este contraste entre a maior força ordenadora da solução teórica de Fernandes ante o constructo de Germani pode apontar inclusive para certas conexões pouco óbvias entre teoria sociológica e processo social. Com certo risco de simplificação, podemos dizer que, longe de serem apenas preferências intelectuais, estas diferenças teóricas traduzem também diferenças básicas entre as sociedades brasileira e argentina. Mesmo que possamos reuni-las sobre a rubrica dos casos não clássicos de revolução burguesa, a dissociação entre desenvolvimento e democracia que é típica desses processos 
se coloca de maneira diferenciada num caso e no outro. No caso brasileiro, há muito mais nitidez quanto ao caráter estruturalmente excludente de seu padrão de mudança social, o que dá suporte à detecção de certa linha de continuidade histórica, a despeito da marcha ziguezagueante imposta pelo capitalismo dependente. Nos argumentos de Fernandes, essa continuidade residiria no caráter autocrático da transformação capitalista. Já no caso argentino, a experiência intersubjetivamente compartilhada quanto ao caráter excepcional desta sociedade, que teria dado marcha-ré em seu processo de modernização (Kozel, 2007) - afinal, a certa altura de sua história, a Argentina parecia ter cumprido efetivamente a maioria das prerrogativas modernas - não daria guarida a generalizações deste tipo. Daí, no esquema teórico de Germani, a multiplicação das instâncias explicativas e a radicalização da dimensão contingente: dada a opacidade dessa experiência social - o paradoxo argentino -, a análise sociológica precisaria se agarrar a todas as asperezas da matéria social a fim de lhe captar o sentido. ${ }^{11}$ Este contraste entre clareza e opacidade, com perdão do esquematismo, estaria na base dos procedimentos diversos de teorização empregados por Fernandes e Germani: o primeiro, usando as especificidades da sociedade brasileira para potenciar a generalização; o segundo, fazendo do exemplo argentino uma contraprova cabal dos limites de toda e qualquer generalização.

Não se trata, é claro, de opor certo formalismo de Fernandes ante a teorização mais atenta aos aspectos contingentes por parte de Germani. Vimos que, à contraluz do experimento teórico parsoniano, a análise de Fernandes abria grande espaço à dimensão histórica da explicação sociológica - sua discussão da noção de sistema é patente neste sentido. No fundo, as formas que se precipitaram ao longo do processo de acumulação teórica de Fernandes e Germani são formas difíceis, cujo poder de abstração - mais forte no primeiro que no segundo - jamais pôde descartar sem mais a natureza problemática da matéria social que visavam a ordenar. ${ }^{12} \mathrm{O}$ contraste com a forma do raciocínio sociológico de Parsons, que pôde se desdobrar numa poderosa visada formalista do processo social uma espécie de teleologia da forma: a diferenciação progressiva ao longo do esquema agil apararia todas as arestas históricas encontradas pelo caminho (Domingues, 2001, p. 92) -, ajuda a iluminar esta problemática. Aliás, este confronto sistemático entre soluções teóricas feitas no centro e nas duas periferias não nos ajuda só a repensar as mediações entre teoria sociológica e processo social no caso das últimas, mas também no âmbito da primeira. A relativa liberdade de Parsons, que se propôs a ordenar teoricamente o conjunto do desenvolvimento ocidental por meio de um esquema abstrato diferenciação-inclusão, tem a sua contrapartida num chão histórico específico - a sociedade norte-americana - que radicalizou a revolução burguesa a ponto de ofuscar até mesmo a importância de suas próprias contingências e especificidades (Offe, 2006). Ou, noutros termos, como se fosse possível entender a dinâmica do mundo diretamente a partir da sociedade norte-americana, sem mediaçóes históricas (Steinmetz, 2007b).

Em resumo, ao analisarmos os capítulos brasileiro e argentino da sociologia nos anos de 19601970 , divisando os resultados criativos de suas respectivas traduçôes da sociologia dominante de seu tempo - a sociologia norte-americana, aqui metonimizada pela teorização parsoniana -, procuramos demonstrar três pontos principais. $\mathrm{O}$ primeiro, que as práticas de importação-exportação da teoria sociológica - como dos demais produtos intelectuais não geram simplesmente uma maior homogeneização: o termo tradução insiste justamente nos inevitáveis deslocamentos impostos continuamente pelos novos pressupostos sociais ao produto importado. O segundo, que as consequências da tradução não se manifestam apenas nos níveis mais imediatos $\mathrm{da}$ teorização sociológica, mas atuam também na sua forma. O terceiro, tendo em vista as possibilidades de captação de mediações históricas entre forma da teoria sociológica e especificidade da matéria social, a análise aqui desenvolvida pôde divisar em termos críticos simultaneamente a reflexão feita no centro e na periferia. É como se, ao fim e ao cabo, a partir da periferia pudéssemos estabelecer uma plataforma de observação da teoria sociológica como um todo, sem minimizar nem as desigualdades, nem as variedades existentes no interior do conjunto por ela formado. 


\section{Notas}

1 Apesar deste artigo se referir à somente produção sociológica, esta relação problemática entre vida cultural e experiência periférica se espraia virtualmente para todos os campos da cultura. Para ficarmos em alguns exemplos brasileiros e argentinos, já tratados em diversos trabalhos: literatura (Candido, 2006; Prieto, 1969; Sarlo, 2007; Schwarz, 2000), filosofia (Arantes, 1994; Terán, 1993), marxismo (Altamirano, 2001; Ricupero, 2000), artes plásticas (Giunta, 2001; Naves, 1996).

2 A despeito de suas trajetórias biográficas inverossímeis (Miceli, 2012), Florestan Fernandes e Gino Germani chefiaram, respectivamente, a Cátedra de Sociologia I da Universidade de São Paulo e o Departamento de Sociologia da Universidade de Buenos Aires. Para uma análise consistente do papel que ambos desempenharam na renovação da sociologia no Brasil e na Argentina, cf. Arruda (2001) e Blanco (2006).

3 Se, por um lado, a relação ao mesmo tempo intensa e heterodoxa de Florestan Fernandes com o estrutural-funcionalismo já constitui ponto pacífico em sua fortuna crítica (Bastos, 1996; Cohn, 1986; Mariosa, 2003), no caso de Gino Germani ainda persiste uma visão muito simplificada de suas relações intelectuais com a obra de Talcott Parsons. Para alguns intérpretes, Germani aplicaria mecanicamente esta vertente teórica à realidade argentina (Rodríguez, 2009) No entanto, novas interpretações mais matizadas e consistentes vêm questionando esta visão (Blanco, 2003; Domingues, 2007).

4 Em carta a Edward A. Tiryakian, já no final da vida, Talcott Parsons explicita algumas das razōes desta sua virada para uma visão mais positiva da sociedade moderna (Parsons, 1979).

5 A noção de dilema, como o próprio termo sugere, leva necessariamente à análise da qualidade das opções societárias em jogo, quer dizer, de como os círculos sociais procuram atacar (ou não) o próprio dilema. Para uma análise desta questão nos textos do autor, cf. Cohn (1986).

6 Este ponto de partida teórico de Gino Germani está diretamente associado às suas tentativas de elucidação do fascismo . O autor, italiano de nascimento, emigrou para a Argentina justamente em virtude das perseguições (incluindo prisōes etc.) que enfrentou no seu país de origem em função de sua militância antifascista (A. Germani, 2004).

7 A noção de tipo extremo, desenvolvida por Florestan
Fernandes em Fundamentos empíricos da explicação sociológica [1959] na esteira de sua reconstrução das formulações de Marx, tem a seguinte definição: "Por seu caráter mesmo, é claro que as generalizações [...] valem, empiricamente, para o sistema social que realiza o tipo extremo. Mas, como são generalizações relativas a caracteres essenciais de fenômenos variáveis, [...] se aplicam aos demais sistemas que possam tender para o padrão inerente ao tipo extremo, encarnado pelo sistema social investigado" (Fernandes, 1967, pp. 134-135, grifo no original).

8 Em exemplo claro deste acionamento explicativo dos "acidentes históricos" podemos ver no seguinte trecho, em que o autor discute as causas do fim do período "radical" (1916-1930): "Dados acidentais se agregaram posteriormente aos elementos referidos à estrutura econômica, social e política do país, e seu peso não deve ser subestimado. Estes fatores são: a idade do Presidente Irigoyen - o líder carismático que liderou o movimento por longo tempo -, a desordem administrativa da segunda presidência, atos politicamente arbitrários e a queda consequente da popularidade do regime, como demonstrado nas eleiçóes legislativas de 1930" (Germani, 1978, p. 149).

9 Embora nosso material não seja literatura, mas teoria sociológica, seguimos aqui as referências fundamentais de Antonio Candido (2000) quanto à qualificação do social como mais um elemento interno da composição textual.

10 É curioso notar que Maria Sylvia de Carvalho Franco (1970), apesar de criticar duramente a teorização de Gino Germani como uma simples especificação do estrutural-funcionalismo de Parsons às condições da América Latina, também tenha se referido - noutra chave teórica, é claro - à necessidade de se incorporar as contingências históricas como um limite às generalizaçōes. Para este ponto, cf. Botelho (2012).

11 Beatriz Sarlo (2007, p. 335) nos remete à seguinte afirmação presente no romance Hay cenizas en el viento [1982], de Carlos Dámaso Martínez: "Sarmiento acreditava que [a Argentina] era um enigma que podia ser desvendado. Se tivesse vivido o que vivi, teria escrito outro Facundo. Ou não teria escrito nada".

12 Tomei de empréstimo a noção de forma difícil discutida por Rodrigo Naves (1996) em sua análise das artes plásticas no Brasil. Que o mesmo problema se apresente em outro campo da produção cultural é revelador de um problema mais amplo, que tem a ver com as dificuldades de ordenação intelectual de experiências históricas periféricas. No argumento 
de Naves, é possível ver no andamento dos principais artistas brasileiros a passagem de uma "dificuldade de forma" para uma "forma difícil", isto é, uma forma com pouca potência ordenadora, incapaz de submeter os materiais à vontade violenta do criador. Para Naves, isto seria particularmente visível nas estruturas em ferro de Amílcar de Castro e nas telas em têmpera de Alfredo Volpi, que conseguem estilizar o desgaste do tempo (isto é, uma certa densidade histórica), realizando uma espécie de "construtivismo às avessas".

\section{BIBLIOGRAFIA}

ALEXANDER, J. (1984), Theoretical logic in sociology. Vol. 4: The modern reconstruction of classical thought: Talcott Parsons. London, Routledge $\&$ Kegan Paul.

. (1987), Twenty lectures. Nova York, Columbia University Press.

ALTAMIRANO, C. (2001), Peronismo y cultura de izquierda. Buenos Aires, Temas.

AMARAL, S. (2009), "Del fascismo al movimiento nacional-popular: el peronismo y el intercambio Germani-Lipset, 1956-1961". Buenos Aires, Universidad del CEMA, Documento de Trabajo $\mathrm{n}^{\circ} 402$.

ARANTES, P. E. (1994), Um departamento francês de ultramar. São Paulo, Paz e Terra.

ARRUDA, M. A. do N. (2001), Metrópole e cultura: São Paulo no meio século XX. Bauru, SP, Edusc.

(2009), "Florestan Fernandes: vocação científica e compromisso de vida", in A. Botelho e L. Schwarcz (orgs.), Um enigma chamado Brasil, São Paulo, Cia. das Letras.

BASTOS, E. R. (1987), "A questão racial e a revolução burguesa”, in M. A. D’Incao (org.), O saber militante: ensaios sobre Florestan Fernandes, Rio de Janeiro/São Paulo, Paz e Terra/Editora da Unesp.

(1996), "Octavio Ianni: a questão racial e a questão nacional", in M. I. L. Faleiros e R. A. Crespo (orgs.), Humanismo e compromisso: ensaios sobre Octavio Ianni, São Paulo, Editora da Unesp.

(2002), "Pensamento social da escola sociológica paulista", in S. Miceli (org.), O que ler na ciência social brasileira, São Paulo, Sumaré/Anpocs.

BEIGEL, F. (dir.). (2010), Autonomía y dependencia académica. Buenos Aires, Biblos.

BENDIX, R. (1967), "Tradition and modernity reconsidered". Comparative Studies in Society and History, 9 (3): 292-346.

BLANCO, A. (2003), "Política, modernización y desarrollo: una revisión de la recepción de Talcott Parsons en la obra de Gino Germani”. Estudios Sociológicos de El Colegio de México, XXI (63): 667-699

(2006), Razón y modernidad: Gino Germani y la sociología en la Argentina. Buenos Aires, Siglo xxi.

(2007), "Ciências sociais no cone sul e a gênese de uma elite intelectual (1940-1965). Tempo Social, 19 (1): 89-114

BOTELHO, A. (2012), "Teoria e história na sociologia política brasileira: a crítica de Maria Sylvia de Carvalho Franco". Trabalho apresentado no $36^{\circ}$ Encontro Nacional da Anpocs, Águas de Lindóia.

BRASIL JR., A. (2010), "O imigrante e seus irmãos”. Lua Nova, 81: 175-213 (2011), Passagens para a teoria sociológica: Florestan Fernandes e Gino Germani. Tese de doutorado. Rio de Janeiro, ppgsa/ifcs/ufrj.

CALHOUN, C. \& VANANTWERPEN, J. (2007), "Orthodoxy, heterodoxy, and hierarchy: mainstream sociology and its challengers", in C. Calhoun (ed.), Sociology in America: a history, Chicago, The University of Chicago Press.

CANDIDO, A. (2000), Literatura e sociedade. São Paulo, T. A. Queiroz. (2006), Formação da literatura brasileira. 10 ed. Rio de Janeiro, Ouro sobre Azul. COHN, G. (1986), "Padrōes e dilemas", in R. Moraes et al., Inteligência brasileira, São Paulo, Brasiliense.

(2001), "A revoluçãao burguesa no Brasil", in L. D. Mota (org.), Introdução ao Brasil: um banquete nos trópicos. 3 ed. São Paulo, Senac. CONNELL, R. (2006), "Northern Theory: The political geography of general social theory". Theory and Society, 35 (2): 237-264 
DOMINGUES, J. M. (2001), A sociologia de Talcott Parsons. Niterói, Editora da UFF.

(2007), Aproximaçôes à América Latina: desafios contemporâneos. Rio de Janeiro, Civilização Brasileira.

FERNANDES, F. (1967), Fundamentos empiricos da explicação sociológica. São Paulo, Cia. Editora Nacional.

(1975), Sociedade de classes e subdesenvolvimento. 3 ed. Rio de Janeiro, Zahar Editores.

(1976), A sociologia numa era de revolução social. 2 ed. Rio de Janeiro, Jorge Zahar Editores.

(1979), Mudanças sociais no Brasil. 3 ed. São Paulo, Difel.

(1981), Capitalismo dependente e classes sociais na América Latina. 3 ed. Rio de Janeiro, Zahar Editores.

(2006), A revolução burguesa no Brasil.

São Paulo, Globo.

(2008), A integração do negro na socie-

dade de classes. São Paulo, Globo, vol. 2.

FRANCO, M. S. C. (1970), O moderno e suas diferenças. Tese de Livre Docência, FFLCH/USP, São Paulo.

GERHARDT, U. (2002), Talcott Parsons: an intellectual biography. Cambridge, Cambridge University Press.

GERMANI, G. (1956), "La integración de las masas a la vida política y el totalitarismo", Cursos y Conferencias, 48 (273): 153-176.

(1962), "Clases populares y democracia representativa en América Latina”. Desarrollo Económico, 2 (2): 23-43.

(1963), "La movilidad social en la Argentina", in R. Bendix e S. Lipset, La movilidad social en la sociedad industrial, Buenos Aires, Eudeba (Apéndice II).

(1965), "Hacia una democracia de masas", in Di Tella et al., Argentina, sociedad de masas, Buenos Aires, Eudeba.

(1969), La sociología de la modernización. Buenos Aires, Paidós.

(1978), Authoritarianism, fascism and national populism. New Jersey, Transaction Books.
(1981), The sociology of modernization.

New Jersey, Transaction Books. . (2006), Gino Germani: la renovación intelectual de la sociología Comp. Alejandro Blanco. Bernal (Quilmes), AR, Universidad Nacional de Quilmes.

GERMANI, A. A. (2004), Gino Germani: del antifascismo a la sociología. Buenos Aires, Taurus.

GIDDENS, A. (2003), A constituição da sociedade. 2 ed. São Paulo, Martins Fontes.

GILMAN, N. (2003), The mandarins of the future. Baltimore/London, The John Hopkins University Press.

GIUNTA, A. (2001), Vanguardia, internacionalismo y politica: arte argentino en los años sesenta. Buenos Aires, Paidós.

HUGUES, H. S. (1975), The sea change: the migration of social thought, 1930-1965. Nova York, McGraw-Hill Book Co.

KOZEL, A. (2007), "En torno a la desilusión argentina”. Vária História, 23 (38): 368-385.

MAIA, J. M. E. (2012), "Reputaçôes à brasileira: o caso de Guerreiro Ramos". Sociologia \& Antropologia, 2: 265-291.

MAIO, M. C. (1997), A história do Projeto Unesco: estudos raciais e ciências sociais no Brasil. Tese de doutorado. Rio de Janeiro, Iuperj.

MARIOSA, D. (2003), Hibridismo e integração nas obras de Florestan Fernandes. Dissertação de mestrado. Campinas, IFCH/Unicamp.

MICELI, S. (2012), Vanguardas em retrocesso. São Paulo, Cia. das Letras.

NAVES, R. (1996), A forma difícil: ensaios sobre arte brasileira. São Paulo, Ática.

OFFE, C. (2006), Autorretrato a distancia. Buenos Aires, Katz.

PARSONS, T. (1964a), The social system. Nova York, The Free Press.

(1964b), Essays in sociological theory. Nova York, The Free Press.

(1964c), "Evolutionary universals in society". American Sociological Review, 29 (3): 339-357

(1967), Sociological theory and modern society. Nova York, The Free Press.

(1969), Politics and social structure. Nova York, The Free Press. 
(1970), Social structure and personality. Nova York, The Free Press.

(1971), "Comparative studies and evolutionary change", in I. Vallier (ed.), Comparative methods in sociology, Berkeley, University of California Press.

(1974), O sistema das sociedades modernas. São Paulo, Pioneira. (1977), Social systems and the evolution of action theory. Nova York, The Free Press. . (1979), "Letter from Talcott Parsons". Sociological Inquiry, 51 (1): 35-36.

PARSONS, T. \& PLATT, G. M. (1973), The American university. Cambridge, MA, Harvard University Press.

PRIETO, A. (1969), Estudios de literatura argentina. Buenos Aires, Galerna.

RICUPERO, B. (2000), Caio Prado Jr. e a nacionalização do marxismo. São Paulo, Editora 34.

RODRÍGUEZ, C. A. (2009), "Germani y el estructural-funcionalismo, evolucionismo y fe en la razón: aspectos de la involución irracional”. Universum, 24 (1): 12-20.

SARLO, B. (2007), Escritos sobre literatura argentina. Buenos Aires, Siglo XXI.

SARLO, B. \& ALTAMIRANO, C. (2007), La batalla de las ideas. Buenos Aires, Emecé.

SCHWARZ, R. (2000), Um mestre na periferia do capitalismo. São Paulo, Editora 34.

SILVA, M. A. M. (2012), "Fazer história, fazer sentido: Associação Cultural do Negro (19541964)". Lua Nova, 85: 227-273.

STEINMETZ, George. (2007a), "American sociology before and after World War II: the (temporary) settling of a disciplinary field", in C. Calhoun (org.), Sociology in America: a history, Chicago, The University of Chicago Press. . (2007b), "The relations between sociology and history in the United States: the current state of affairs". Journal of Historical Sociology, 20 (1-2): 1-12

TERÁN, O. (1993), Nuestros años sesentas. Buenos Aires, El Cielo por Asalto.

TRINDADE, H. (org.). (2007), As ciências sociais na América Latina em perspectiva comparada (1930-2005). 2 ed. Porto Alegre, Editora da UFRGS.
WEARNE, B. C. (2009), The theory and scholarship of Talcott Parsons to 1951. Cambridge, Cambridge University Press. 


\section{LINHAS RETAS OU LABIRINTOS? A TRADUÇÃO DA SOCIOLOGIA DA MODERNIZAÇÃO NOS TEXTOS DE FLORESTAN FERNANDES E DE GINO GERMANI (1960-1970)}

\section{Antonio Brasil Jr.}

Palavras-chave: Pensamento social; Sociologia do desenvolvimento; Florestan Fernandes; Gino Germani; Talcott Parsons.

Neste artigo, analisaremos como Florestan Fernandes e Gino Germani, ao traduzirem a sociologia da modernização norte-americana às especificidades das sociedades brasileira e argentina, respectivamente, conseguiram realizar sínteses teóricas criativas. A fim de divisar este potencial teórico, contrastaremos as formulaçôes desses dois autores com os argumentos de Talcott Parsons, figura fundamental na sistematização da sociologia da modernização. Entendendo o processo de tradução como um fenômeno intelectual dinâmico, recuperamos os principais textos de Fernandes, Germani e Parsons dos anos de 1960-1970, período decisivo no qual foram ganhando clareza os deslocamentos recíprocos entre as suas teorizações.

\section{STRAIGHT LINES OR A LABYRINTH? THE TRANSLATION \\ OF THE SOCIOLOGY OF MODERNIZATION ON THE TEXTS OF FLORESTAN FERNANDES AND GINO GERMANI (1960-1970)}

Antonio Brasil Jr.

Keywords: Social thought; Sociology of development; Florestan Fernandes; Gino Germani; Talcott Parsons.

This article discusses how Florestan Fernandes and Gino Germani, in translating the American sociology of modernization to the specificities of the Brazilian and Argentinean societies, respectively, succeeded in achieving creative theoretical syntheses. In order to discern such theoretical potential, the article contrasts the formulations of those authors with the arguments of Talcott Parsons, a fundamental figure in the systematization of the sociology of modernization. Understanding the process of translation as a dynamic intellectual phenomenon, the article recoups the main texts of Fernandes, Germani, and Parsons, of the years 1960-1970, a decisive period in which the reciprocal displacements between their theorizations were becoming clearer.

\section{LIGNES DROITES OU LABYRINTHES ? LA TRADUCTION DE LA SOCIOLOGIE DE LA MODERNISATION DANS LES TEXTES DE FLORESTAN FERNANDES ET DE GINO GERMANI (1960-1970)}

Antonio Brasil Jr.

Mots-clés: Pensée sociale; Sociologie du développement; Florestan Fernandes; Gino Germani; Talcott Parsons.

Dans cet article nous analyserons comment Florestan Fernandes et Gino Germani, en traduisant la sociologie de la modernisation nord-américaine aux spécificités des sociétés brésilienne et argentine, ont réussi à réaliser des synthèses théoriques créatrices. Dans le but de partager ce potentiel théorique, nous contrasterons les formulations de ces deux auteurs avec les arguments de Talcott Parsons, personnage fondamental dans la systématisation de la sociologie de la modernisation. En comprenant le processus de traduction en tant que phénomène intellectuel dynamique, nous récupérons les principaux textes de Fernandes, Germani et Parsons des années 1960-1970, période décisive dans laquelle les déplacements réciproques ont gagné en clarté parmi leurs théorisations. 